\title{
Reklama w konwencji zwiastuna filmowego - perswazja czy manipulacja?
}

\section{Wprowadzenie}

Badania przeprowadzone przez CBOS pokazują, że 86\% Polaków nie lubi oglądać reklam, według $80 \%$ respondentów przekazy te są nudne, $81 \%$ przyznaje zaś, że reklamy bywają denerwujące ${ }^{1}$. Takie nastawienie odbiorców stawia przemysł reklamowy przed nie lada wyzwaniem. Jak bowiem przyciągnąć uwagę widza, który natrafiając na blok reklamowy w telewizji, najczęściej po prostu zmienia kanał? Ratunkiem może okazać się advertainment, czyli połączenie reklamy z zabawą i rozrywką (ang. advertising - 'reklama', entertainment - 'rozrywka'). Jedną z jego audiowizualnych form jest reklama w konwencji trailera.

Główne pytanie badawcze dotyczy tego, czy odbiorca takiego przekazu jest świadomy, że ogląda reklamę produktu/marki. Uzyskanie informacji na temat stopnia uświadomienia faktycznego celu, jaki ma wywołać komunikat (budowanie obrazu konkretnej marki), pomoże określić, z jaką formą wywierania wpływu - perswazją czy manipulacją - mamy do czynienia w przypadku tytułowych przekazów. Podstawowe hipotezy, które mają zostać zweryfikowane w zaprojektowanym badaniu, brzmią następująco:

1. Odbiorcy nie są świadomi, że oglądają komunikat reklamowy.

2. Reklamy w konwencji trailera sa bliższe manipulacji niż perswazji.

3. Odbiorcy wykazuja większe zainteresowanie przekazem podczas ogladania reklam $w$ konwencji zwiastuna filmowego niż $w$ czasie odbioru tradycyjnych spotów reklamowych.

* Dr, Katedra Dziennikarstwa i Komunikacji Społecznej, Uniwersytet Łódzki, e-mail: agabarczyk@gmail.com.

1 Zob. CBOS: ponad 85 proc. Polaków nie lubi reklam, http://www.wirtualnemedia.pl/artykul/ cbos-ponad-85-proc-polakow-nie-lubi-reklam [dostęp: 18.02.2017]. 


\section{Agnieszka Barczyk-Sitkowska}

Artykuł podzielony został na trzy części. Na początku przywołano definicje niezbędnych pojęć (advertainment, trailer), które budują kontekst zasadniczych rozważań. W głównej części tekstu zaprezentowane zostało badanie ankietowe przeprowadzone w dniach 18-25 lutego 2017 r. W ostatnim fragmencie znajdują się wnioski płynące $\mathrm{z}$ przeprowadzonego badania.

\section{Między reklamą a rozrywką}

Advertainment - w przeciwieństwie do tradycyjnej reklamy - rezygnuje z powszechnej prezentacji produktu na rzecz budowania fabuły, zabawnych sytuacji, nawiązań do innych tekstów kultury i przekazów rozrywkowych. Jednocześnie reklamo-rozrywka nie jest tym samym, co lokowanie produktu, będące - jak pisze Cristel Antonia Russell - tylko jednym z jego typów: „w product placement towaru nie reklamuje się wprost, lecz przy okazji powstałej fabuły, natomiast w wypadku advertainment fabuła tworzona jest wokół produktu"2 . Oprócz wspomnianego już lokowania produktu, zdaniem przywoływanej badaczki, reklamo-rozrywka obejmuje również: product integration oraz branded entertainment ${ }^{3}$.

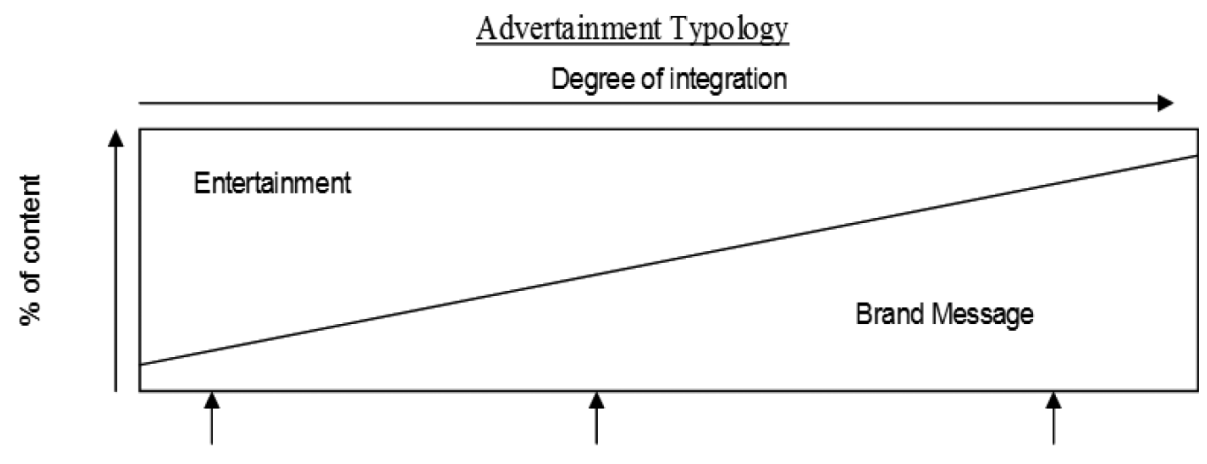

Product placement

Product Integration

Branded Entertainment

Wykres 1. Typy advertainment

Źródło: C.A. Russell, Advertainment: Fusing Advertising and Entertainment, Michigan 2007, s. 5.

W przypadku lokowania produktu reklamowana marka umieszczona zostaje w obrębie dowolnego tekstu kultury, np. Aston Martin w filmach o przygodach

2 D. Gut, Kieszonkowe kino, https://www.wprost.pl/tygodnik/43177/Kieszonkowe-kino.html [dostęp: 18.02.2017]. O różnicach między advertainment i product placement piszą m.in. Margaret Craig-Lees i Jane Scott. Zob. G. Ptaszek, Rozrywka w służbie reklamy (advertainment), czyli jak uśpić czujność konsumenta, „Naukowy Przegląd Dziennikarski” 2015, nr 4, s. 67.

3 Zob. C.A. Russell, Advertainment: Fusing Advertising and Entertainment, Michigan 2007, s. 4-8. 
Jamesa Bonda. Bardziej zaawansowanym typem reklamo-rozrywki jest product integration, przy okazji którego produkt przestaje być tylko rekwizytem i staje się ważnym składnikiem świata przedstawionego, np. wywołuje dylemat bohatera, napędza jego działania, staje się tematem rozmów (jako przykład może posłużyć serial Big Bang Theory - jeden z bohaterów rozważa, jaką konsolę do gier kupić - PS4 czy XBOX 360$)^{4}$. Najciekawszą formą wydaje się branded entertainment, czyli komunikat rozrywkowy stworzony na potrzeby konkretnej marki. Jako pierwszy przykład tego zjawiska podaje się często kampanię The Hire - serię krótkometrażowych filmów przygotowanych przez BMW w latach 2001-20025

Za jedną z audiowizualnych form reklamo-rozrywki Grzegorz Ptaszek uznaje reklamę, która używa kodów zarezerwowanych dla zwiastuna filmowego (trailera) ${ }^{6}$, czyli krótkiego materiału audiowizualnego, zmontowanego $\mathrm{z}$ najciekawszych fragmentów promowanego filmu, pełniącego jednocześnie funkcję informacyjną i perswazyjną - jest on bowiem zapowiedzią utworu i jego reklamą. Zasadniczo wyróżnia się trzy typy zwiastunów: zwiastun kinowy (trailer), wstępną zapowiedź (teaser trailer) oraz spot telewizyjny. Poszczególne rodzaje różnią się długością, polami dystrybucji oraz czasem, w jakim są wyświetlane ${ }^{7}$. W przypadku przekazów wpisujących się w obszar reklamo-rozrywki mamy do czynienia ze szczególną sytuacją, gdyż - jak zauważa Ptaszek - „zwiastun filmowy ma charakter czysto fikcjonalny, ponieważ stanowi zapowiedź filmu, który nie istnieje"8. Przekaz wyjściowy, który ma wpłynąć na odbiorcę, stanowi komunikat perswazyjny niebezpiecznie wkraczający w pole manipulacji, w przypadku której „nadawca nie tylko nie uświadamia odbiorcy swojego pragmatycznego celu, ale próbuje go maskować, albo wskazywać na inny cel od faktycznie zamierzonego"9. Przywoływane reklamy nie tylko ukrywają, że mają za zadanie przede wszystkim zachęcić do konkretnej marki lub wytworzyć wokół niej sieć pozytywnych skojarzeń, ale wręcz wyraźnie wskazują na inny cel - rzekomo mają stanowić zapowiedź filmu. Pojawia się zatem pytanie: jak faktycznie przekazy te sq odbierane przez widzów?

4 Zob. Advertainment - przyciagnij uwage widza!, https://poradnikprzedsiebiorcy.pl/-advertainment-przyciagnij-uwage-widza [dostęp: 18.02.2017].

5 Zob. C.A. Russell, dz. cyt., s. 6.

6 Zob. G. Ptaszek, dz. cyt. s. 73. Autor omawia tę formę na przykładzie zwiastuna marki Mike\&lke.

7 Zob. W. Mosiejczuk, Zwiastun jako gatunek filmowy, http://blog.mosiejczuk.pl/zwiastun-jako-gatunek-filmowy [dostęp: 19.02.2017].

8 G. Ptaszek, dz. cyt. s. 74.

9 G. Habrajska, Nakłanianie, perswazja, manipulacja językowa, „Folia Litteraria Polonica” 2005, nr 7, s. 120. 


\section{Agnieszka Barczyk-Sitkowska}

\section{Prezentacja badania}

Celem badania ankietowego, przeprowadzonego w dniach 18-25 lutego 2017 r., była przede wszystkim próba znalezienia odpowiedzi na pytanie o to, jak ankietowani odbierają prezentowane im przekazy - czy postrzegają je jako komunikaty reklamowe dedykowane konkretnym markom, czy widzą w nich wyłącznie zwiastuny filmowe?

W przeprowadzonym badaniu wzięło udział 106 respondentów (75 kobiet i 31 mężczyzn). Wśród ankietowanych dominowały osoby w wieku 18-29 lat (78 respondentów). 19 badanych reprezentowało przedział 30-39 lat, cztery osoby należały do grupy wiekowej 40-49, pięciu respondentów miało mniej niż 18 lat. Warto zwrócić uwagę, że $68,9 \%$ badanych to osoby posiadające wykształcenie wyższe lub wyższe niepełne. W gronie respondentów znalazło się zatem wielu studentów lub osób, które niedawno skończyły studia.

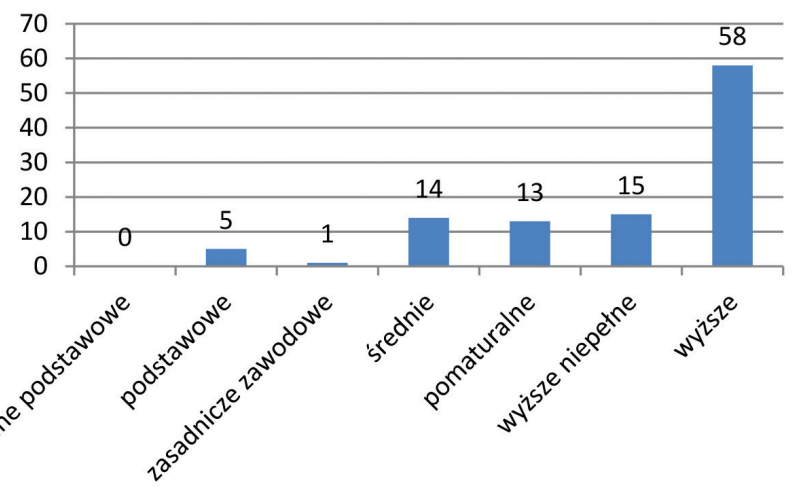

Wykres 2. Wykształcenie respondentów Źródło: opracowanie własne.

Wszyscy badani są użytkownikami mediów społecznościowych (zaproszenie do badania rozsyłane było za pomocą Facebooka). Kwestionariusz składającej się z 14 pytań ankiety umieszczony został w serwisie internetowym www.ebadania. $\mathrm{pl}^{10}$. Część pytań miała charakter otwarty, co z jednej strony, spowodowane było chęcią zaoferowania respondentom możliwie szerokiej swobody w udzielaniu odpowiedzi (i niesugerowania interpretacji przekazów), z drugiej - pozwalało na zaznaczenie w wypowiedzi, że nie wszystkie materiały audiowizualne prezentowane w badaniu zostały przez daną osobę obejrzane.

Pierwsze trzy pytania miały pomóc określić stosunek ankietowanych do reklamy oraz częstotliwość, z jaką uczęszczają oni do kina. Okazało się, że 95,3\% badanych odwiedza kino przynajmniej kilka razy w roku (9,4\% nawet częściej niż raz

10 Zob. http://www.ebadania.pl/index.php [dostęp: 25.02.2017]. 
w miesiącu). Można zatem przyjąć, że badani stosunkowo często obcują z formą, jaką jest zwiastun filmowy.

Kolejne pytanie potwierdziło wyniki badań przeprowadzonych przez CBOS (mówiące, że zdecydowana większość Polaków nie lubi oglądać reklam). Jedynie 10 respondentów zadeklarowało pozytywny stosunek do tej formy przekazu. Nieco zaskakujący może być natomiast fakt, że aż 49 badanych określiło swój stosunek jako obojętny.

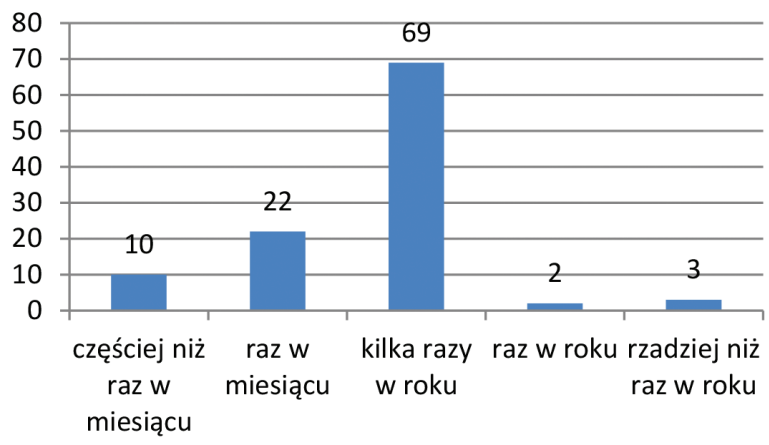

Wykres 3. Częstotliwość uczęszczania do kina Źródło: opracowanie własne.

Co ciekawe, większość ankietowanych - także ci, którzy deklarowali obojętny stosunek do reklamy - nie lubi oglądać przekazów reklamowych w kinie. Jedynie 20 osób $(18,9 \%)$ podchodzi pozytywnie do takiej aktywności. Można zatem przypuszczać, że duża grupa ankietowanych nie będzie zainteresowana przekazami, które zostaną wykorzystane podczas badania, gdyż znaczną część reklam prezentowanych w kinie stanowią właśnie zwiastuny.

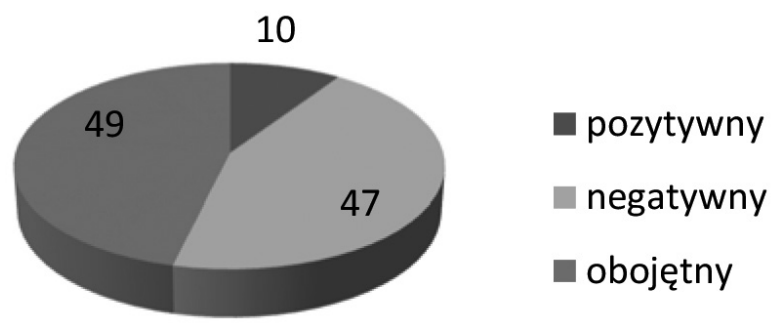

Wykres 4. Stosunek respondentów do reklamy (liczba wskazań) Źródło: opracowanie własne.

Trzy kolejne pytania dotyczyły materiałów audiowizualnych, reprezentujących analizowane zjawisko. Były to kolejno: Lucky Star (2002) ${ }^{11}$, The Return of

11 Zob. https://www.youtube.com/watch?v=YoCLxp2W9xE [dostęp: 1.03.2017]. 
Mike and Ike (2013) ${ }^{12}$ oraz The Tale of Thomas Burberry (2016) ${ }^{13}$. Wszystkie przywoływane przekazy odwołują się do konwencji zwiastuna filmowego i wyraźnie nawiązują do wielu elementów jego schematu dramaturgicznego - po kilku ujęciach wprowadzających następuje krótkie streszczenie historii (oczywiście zakończenie pozostaje tajemnicą), po nim zaś pojawia się przypominająca teledysk sekwencja krótkich, dynamicznie zmontowanych ujęć. Zwieńczeniem całości są napisy - zazwyczaj tytuł i data premiery filmu ${ }^{14}$. Dane zgromadzone w poniższej tabeli pokazują, ilu respondentów zdecydowało się na obejrzenie materiałów, do których odsyłał ich kwestionariusz, ilu zaś zrezygnowało z projekcji (w ogóle lub w jej trakcie).

Tabela 1. Zachowania respondentów wobec trzech prezentowanych trailerów

\begin{tabular}{|c|c|c|c|}
\hline $\begin{array}{c}\text { Czy obejrzałaś/eś zwiastun } \\
\text { w całości? }\end{array}$ & Lucky Star & $\begin{array}{c}\text { The Return of } \\
\text { Mike and lke }\end{array}$ & $\begin{array}{c}\text { The Tale of } \\
\text { Thomas Burberry }\end{array}$ \\
\hline Tak & 60 & 75 & 63 \\
\hline Przerwałam/em w trakcie & 40 & 23 & 30 \\
\hline Nie włączyłam/em & 6 & 8 & 13 \\
\hline
\end{tabular}

Źródło: opracowanie własne.

Dane zgromadzone w Tabeli 1 pokazują, że większość badanych decydowała się na obejrzenie materiału audiowizualnego. Każdy zwiastun został włączony minimum przez $87,7 \%$ respondentów (93 osoby). Należy mieć na uwadze, że nie wszyscy obejrzeli prezentowane przekazy w całości - niektórzy przerywali projekcję, ponieważ materiał był zbyt długi lub zbyt nudny. Osoby, które w ogóle nie zdecydowały się na obejrzenie zwiastunów jako przyczyny swojego zachowania podawały następujące powody: „nie udało się”, „wypełniałem test szybko, robiąc go na telefonie”, „nie lubię oglądać zwiastunów filmów w takiej wymuszonej formie”, "mało zainteresował mnie filmik 1 i 2" (podobna wypowiedź: „podejrzewam, że będzie tak samo mało interesujący jak poprzednie”), „jestem w kościele"15. Warto dodać, że 99 osób nie widziało wcześniej żadnego z prezentowanych trailerów, jedynie sześciu respondentów miało okazję obejrzeć The Tale of Thomas Burberry, a jedna osoba zetknęła się z Lucky Star. Należy zaznaczyć, że pięć osób nie obejrzało żadnego z prezentowanych materiałów, dlatego

12 Zob. https://www.youtube.com/watch?v=MtgcVKsV2sA [dostęp: 1.03.2017].

13 Zob. https://www.youtube.com/watch?v=6D5IZtDCS5c [dostęp: 1.03.2017].

14 Zob. W. Mosiejczuk, dz. cyt.

15 Przykładowe wypowiedzi badanych. 
ich odpowiedzi na pytania dotyczące wykorzystanych w czasie badania plików audiowizualnych nie zostały uwzględnione ${ }^{16}$.

Wyniki potwierdziły jedną ze sformułowanych wcześniej hipotez - znaczna część badanych nie była świadoma, że ogląda reklamę produktu lub marki. Faktycznymi bohaterami prezentowanych zwiastunów były kolejno: Mercedes-Benz, Mike\&Ike oraz Burberry. Natomiast w odpowiedzi na pytanie otwarte: Co zapowiadaja prezentowane przekazy? aż 65 razy pojawił się film 16 osób w ogóle nie potrafiło udzielić odpowiedzi na to pytanie („,nie wiem”, „trudno powiedzieć”, „,nie znam się"). Jedynie w 12 odpowiedziach pojawiło się przynajmniej jedno ze słów: „reklama”, „marka” lub „produkt”. Warto przyjrzeć się przykładowym wypowiedziom: „dwa pierwsze to zwiastuny filmów, trzeci to reklama”, „filmy, drugi to reklama żelek”, „wyglądają na reklamy produktów udające trailery”, „są to reklamy nadchodzących produktów istniejących już marek”, „reklamy różnych produktów”, „produkty handlowe”, „film, produkt, markę". Nawet wśród tych 12 odpowiedzi wskazanie na reklamę komercyjną dotyczyło jedynie wybranych materiałów, niektóre zaś nadal postrzegane były wyłącznie jako zapowiedzi filmów.

Co istotne, większość badanych potrafi podać definicję i cel zwiastuna filmowego. Wśród sformułowanych przez respondentów wyjaśnień analizowanego terminu wyraźnie zaznaczają się dwa sposoby definiowania pojęcia - pierwszy skupiony jest wokół informacyjnych walorów zwiastuna, drugi akcentuje perswazyjną funkcję komunikatu.

Tabela 2. Definicje zwiastuna filmowego

\begin{tabular}{|c|c|}
\hline Walory informacyjne & Walory perswazyjne \\
\hline $\begin{array}{l}\text { Zapowiedź (filmu) - } 25 \\
\text { Wycinek wybranych scen z filmu - } 17 \\
\text { Streszczenie filmu/jego kluczowych wątków - } 10 \\
\text { Film w pigułce - } 2\end{array}$ & $\begin{array}{l}\text { Zachęta do obejrzenia filmu - } 18 \\
\text { Reklama (nowego filmu) - } 9 \\
\text { Pobudzenie ciekawości/zaangażowania widza - } 5\end{array}$ \\
\hline \multicolumn{2}{|l|}{ INNE - przykładowe odpowiedzi ${ }^{17}$} \\
\hline \multicolumn{2}{|l|}{$\begin{array}{l}\text { „dramat, wojna, miłość, romanse i zdrady” } \\
\text { „mrożący krew w żyłach” } \\
\text { „przedsmak tego, co zobaczę w kinie” }\end{array}$} \\
\hline
\end{tabular}

Źródło: opracowanie własne.

\footnotetext{
16 Ankiety te nie zostały jednak odrzucone zupełnie, ponieważ część pytań nie była bezpośrednio związana z prezentowanymi materiałami (dotyczyła znajomości definicji i cech zwiastuna filmowego).

17 W sumie 18 odpowiedzi, najczęstszy był brak definicji.
} 
W pierwszej grupie definicji na czołowe miejsce wysunęło się wyjaśnianie pojęcia poprzez jego rolę, tj. zapowiadanie innego utworu. Pozostałe definicje skupiały się zaś na treści przekazu, który jest streszczeniem, „zlepkiem” wybranych scen z filmu. W drugiej grupie zaakcentowany został wpływ na odbiorcę - czasem dotyczący jedynie aspektu emocjonalnego (pobudzenie ciekawości, zaangażowania widza), zdecydowanie częściej związany z behawioralnym komponentem postawy (zachęta do obejrzenia filmu). Dwóch respondentów w swoich definicjach bardzo wyraźnie wskazało na równoczesne występowanie funkcji informacyjnej i perswazyjnej: „forma zapowiedzi, niosąca w sobie pewne walory informacyjne, a jednocześnie komunikat reklamowy” oraz „forma krótkiej prezentacji filmu mająca na celu przedstawienie zarysu fabuły i zainteresowanie widza"18.

Formułując katalog cech dobrego zwiastuna, badani skupiali się na różnych warstwach przekazu. Na pierwszy plan wysunął się czas trwania materiału i jego tempo. Zdaniem 24 ankietowanych zwiastun powinien być krótki, 26 respondentów zwróciło uwagę na dynamikę przekazu. Część odpowiedzi dotyczyła formalnego ukształtowania przekazu - badani wskazywali na montaż (dynamiczny, ciekawy, sprawny, wykorzystujący ostre cięcia, łączący tylko najlepsze ujęcia z filmu), muzykę (dobrą, odpowiednią, adekwatną, znaną, ciekawą, wyraźną), dialog (dobry, sprytnie poucinany), atrakcyjność wizualną. Dobry zwiastun - podobnie jak film czy reklama - powinien być interesujący, przyciągający uwagę widza, angażujący go emocjonalnie, wyróżniający się na tle innych przekazów. Nie bez znaczenia jest też dramaturgia utworu, budowanie napięcia, zaskakiwanie odbiorcy. W przypadku zwiastuna filmowego szczególnie istotna staje się selekcja, rozumiana jako wybór najciekawszych ujęć z materiału wyjściowego, tj. z reklamowanego filmu. Trailer nie powinien również zdradzać zakończenia filmu, jego rola polega raczej na pokazaniu tyle, by odbiorca poczuł się zaintrygowany i jednocześnie zachęcony do wizyty w kinie. Wykres 5 pokazuje pełen rozkład odpowiedzi respondentów, dotyczących wyznaczników dobrego zwiastuna filmowego. Kategoria „inne” obejmuje osiem cech, które pojawiły się jednokrotnie (zrozumiały, straszny, spójny, śmieszny, patetyczny, prezentujący wyrazistych bohaterów, ukazujący czołowych aktorów, zrealizowany w mrocznej stylistyce).

Niektóre z tych cech - w opinii badanych - można odnaleźć w prezentowanych przykładach. Za najbardziej interesujący uznany został ostatni przekaz - The Tale of Thomas Burberry (52 osoby). 22 respondentów chętnie wybrałoby się na produkcję poświęconą parze gejów (Mike\&Ike), 13 badanych zaciekawiły przygody profesjonalnego hazardzisty, Mr. H. 23 osoby nie chciałyby zobaczyć żadnego $\mathrm{z}$ zapowiadanych filmów ${ }^{19}$. The Tale of Thomas Burberry chwalono m.in. za dobrą muzykę, ciekawe ujęcia, atrakcyjność wizualną, sprawny montaż. Jed-

18 Wypowiedzi badanych.

19 W tym pytaniu można było wybrać kilka odpowiedzi. 

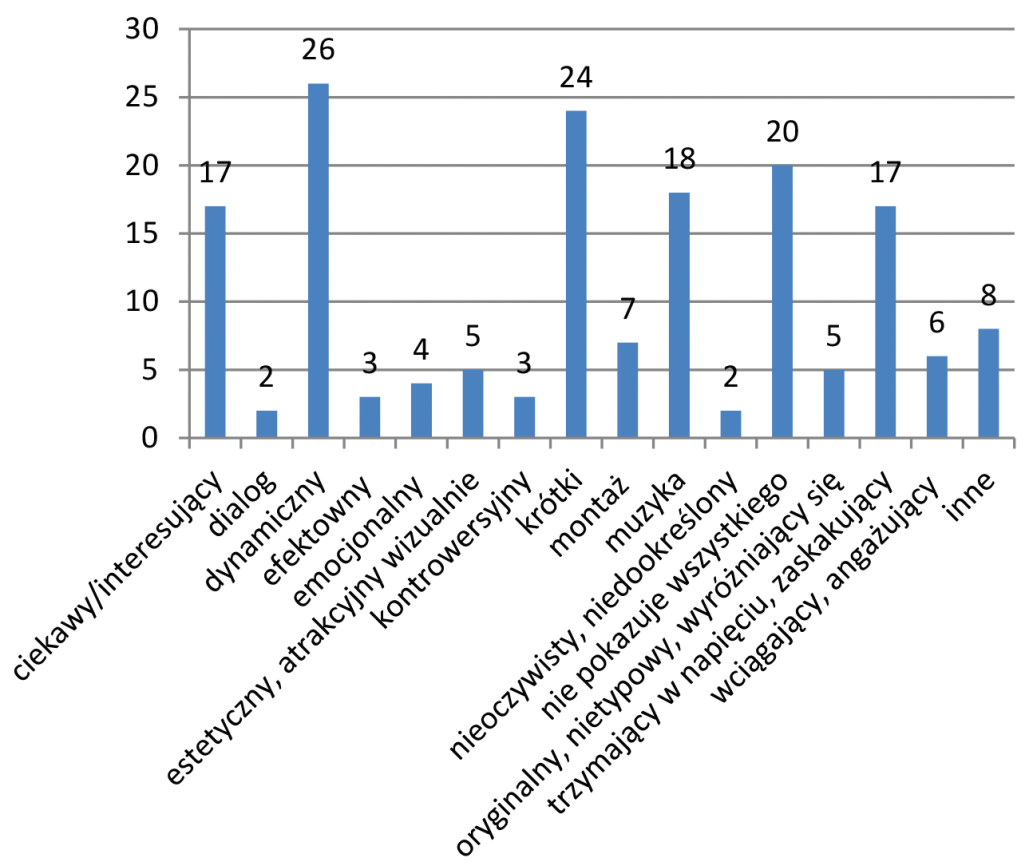

Wykres 5. Cechy dobrego trailera

Źródło: opracowanie własne.

nocześnie dwóch respondentów zauważyło, że ten zwiastun był zbyt długi. Przy okazji drugiego materiału - The Return of Mike and Ike - niektórzy respondenci podkreślali przede wszystkim dynamikę i zwięzłość (to najkrótszy z zaprezentowanych materiałów). Czasem wskazywano także na ciekawą historię, jedna osoba uznała, że przekaz jest śmieszny. Najgorzej wypadł najstarszy przekaz, czyli Lucky Star, wspomniany jedynie przez dwóch ankietowanych, którzy zwrócili uwagę, że jest krótki. 14 respondentów nie dostrzegło żadnej dobrej cechy $\mathrm{w}$ prezentowanych podczas badania materiałach. Może to prowadzić do wniosku, że reklamodawcy sięgający po konwencję zwiastuna filmowego powinni się jeszcze sporo nauczyć (z drugiej strony można jednak zauważyć pewną tendencję wzrostową - najgorzej oceniany był najstarszy przekaz, ocena atrakcyjności rosła przy kolejnych).

Przeprowadzone badanie pokazało, że respondenci znają konwencję zwiastuna filmowego - jego definicję, cechy, funkcję. Mimo posiadania tej wiedzy, w znacznym stopniu mieli problemy z rozszyfrowaniem faktycznego celu prezentowanych komunikatów. Pojawia się zatem pytanie, z czego mogą wynikać te trudności? Być może przyczyny należy upatrywać w nieuważnym oglądzie prezentowanych materiałów. Wydaje się, że wpływ mogła mieć także nieznajomość marek, których dotyczyły przekazy. 


\section{Uwagi końcowe}

W 2007 r. C.A. Russell napisała: „rozrywka i reklama już nie tylko się przecinają, one się połączyły"20. Ta ciekawa z formalnego punktu widzenia fuzja może sprawić kłopoty podczas odbioru współcześnie realizowanych przekazów. Komunikaty perswazyjne, nastawione na zmianę postawy odbiorcy, niebezpiecznie wkraczają w pole manipulacji, w przypadku której „oddziaływanie na odbiorcę ma charakter ukryty"21. Przeprowadzone badanie ankietowe pokazało, iż znaczna grupa odbiorców w ogóle nie była świadoma, że ogląda reklamę komercyjną, w prezentowanych przekazach, świadomie i przekonująco wykorzystujących kody charakterystyczne dla zwiastunów filmowych, doszukiwała się jedynie zapowiedzi filmów. Powtarzające się ujęcia Mercedesa czy drażetek Mike\&Ike interpretowane były jako naturalny składnik świata przedstawionego lub element budowania dramaturgii przekazu. Bohaterowie wykreowani w tekście reklamowym stawali się na tyle atrakcyjni, że część ankietowanych chętnie obejrzałaby film opowiadający o ich przygodach.

Marek Tokarz, dokonując przeglądu zmiennych, których wpływ na zmianę postawy był badany na przestrzeni lat, pisze:

charakterystyka samego komunikatu znalazła między innymi następujący wyraz w badaniach. Komunikaty niesprawiające wrażenia, że ich prawdziwym celem jest nakłonienie słuchacza do czegoś, są na ogół skuteczniejsze od jawnie nakłaniających (Walster i Festinger, 1962) ${ }^{\mathbf{2 2}}$.

Na podobnym mechanizmie opiera się np. reklama natywna. W analogiczny sposób funkcjonują również reklamy imitujące zwiastuny, które udają, że zapowiadają premierę filmu. Ich faktyczny cel - promowanie konkretnego produktu lub marki - zostaje ukryty, przez co nie sprawia wrażenia nachalnego. Forma zwiastuna wydaje się atrakcyjną konwencją przynajmniej z dwóch powodów: po pierwsze - jest krótka, po drugie - dynamiczna. Na te cechy najczęściej zresztą wskazywali respondenci.

Teksty medialne mieszczące się w polu reklamo-rozrywki stanowią ciekawą alternatywę dla tradycyjnej reklamy. Autorzy pracy Storytelling - narracja $w$ reklamie i biznesie, analizując Lucky Star, wskazują na pewien sukces tej kampanii:

20 C.A. Russell, dz. cyt., s. 19. Tłumaczenie własne.

21 G. Habrajska, dz. cyt., s. 120.

22 M. Tokarz, Argumentacja, perswazja, manipulacja, Gdańsk 2006, s. 224. 
oryginalną wersję reżyserską na oficjalnej stronie www.luckystar.com obejrzano 50 tysięcy razy w ciągu czterech tygodni. Mercedes zdobył dane 14 tysięcy potencjalnych kierowców, co doprowadziło do pozyskania 3 tysięcy testujących ${ }^{\mathbf{2 3}}$.

Z perspektywy reklamodawcy reklamo-rozrywka to z pewnością atrakcyjne narzędzie, pomagające przyciągnąć uwagę znudzonego tradycyjnymi spotami widza. A jak to wygląda $z$ perspektywy odbiorcy? Wyniki przeprowadzonego badania pokazują, że oglądający bardzo często dają się oszukać, dekodują przekaz zgodnie $\mathrm{z}$ jego konwencją, a nie $\mathrm{z}$ faktycznym celem. Teraz można by sprawdzić, czy rzeczywiście czują się oni oszukani, ale to już kolejne pytanie badawcze i temat na następny artykuł.

\section{Bibliografia}

Advertainment - przyciagnij uwage widza!, https://poradnikprzedsiebiorcy.pl/-advertainment-przyciagnij-uwage-widza [dostęp: 18.02.2017].

CBOS: ponad 85 proc. Polaków nie lubi reklam, http://www.wirtualnemedia.pl/arty$\mathrm{kul} /$ cbos-ponad-85-proc-polakow-nie-lubi-reklam [dostęp: 18.02.2017].

Fog K., Budtz Ch., Munch P., Blanchette S., Storytelling - narracja w reklamie i biznesie, przeł. J. Wasilewski, B. Brach, Warszawa 2011.

Gut D., Kieszonkowe kino, https://www.wprost.pl/tygodnik/43177/Kieszonkowe-kino.html [dostęp: 18.02.2017].

Habrajska G., Nakłanianie, perswazja, manipulacja jezzkowa , „Folia Litteraria Polonica" 2005, nr 7, s. 91-126.

Mosiejczuk W., Zwiastun jako gatunek filmowy, http://blog.mosiejczuk.pl/zwiastun-jako-gatunek-filmowy [dostęp: 19.02.2017].

Ptaszek G., Rozrywka w slużbie reklamy (advertainment), czyli jak uśpić czujność konsumenta, „Naukowy Przegląd Dziennikarski” 2015, nr 4, s. 62-79.

Russell C.A., Advertainment: Fusing Advertising and Entertainment, Michigan 2007.

Tokarz M., Argumentacja, perswazja, manipulacja, Gdańsk 2006.

23 K. Fog, Ch. Budtz, P. Munch, S. Blanchette, Storytelling - narracja w reklamie i biznesie, przeł. J. Wasilewski, B. Brach, Warszawa 2011, s. 164. 
Agnieszka Barczyk-Sitkowska

\section{Reklama w konwencji zwiastuna filmowego - perswazja czy manipulacja?}

Streszczenie

Znane marki, chcąc przykuć uwagę znudzonego reklamami widza, coraz częściej sięgają po advertainment, czyli połączenie reklamy z zabawą i rozrywką. Przykładem tego zjawiska są reklamy w konwencji zwiastunów filmowych. Celem artykułu jest odpowiedź na pytanie: Czy odbiorca takich przekazów jest świadomy, że ogląda reklamę?

Słowa kluczowe: reklama, zwiastun filmowy, trailer, advertainment

\section{Advertising Imitating a Movie Trailer - Persuasion or Manipulation?}

summary

Popular brands, hoping to catch the attention of a bored spectator, are increasingly using advertainment, which is a combination of advertising, fun and entertainment. An example of this phenomenon is advertising imitating movie trailers. The author tries to answer the question of whether the recipient of such productions is aware that watches advertising?

Keywords: advertising, movie trailer, trailer, advertainment

Agnieszka Barczyk-Sitkowska - dr, absolwentka dziennikarstwa i komunikacji społecznej oraz kulturoznawstwa (specjalność: filmoznawstwo) Uniwersytetu Łódzkiego. Obecnie pracownik Katedry Dziennikarstwa i Komunikacji Społecznej UŁ oraz kierownik Eksperymentalnego Laboratorium Reklamy. Zainteresowania naukowe: telewizja i jej gatunki, reklama telewizyjna, wielokodowość sztuk audiowizualnych. 